\title{
UPAYA MENINGKATKAN SOFTSKILL DISIPLIN MELALUI PENGGUNAAN EDMODO DENGAN METODE BLENDED LEARNING
}

\author{
Murjainah $^{1}$, Kiki Aryaningrum ${ }^{2}$, Arisman $^{3}$ \\ 1,2 Program Studi Pendidikan Geografi, Universitas PGRI Palembang \\ ${ }^{3}$ Program Studi Pendidikan Olahraga, Universitas PGRI Palembang \\ Imurjainah@gmail.com
}

\begin{abstract}
Abstrak. Tujuan dalam penelitian ini adalah untuk mengetahui peningkatan disiplin mahasiswa pendidikan geografi melalui penggunaan Edmodo dengan metode blended learning. Metode yang digunakan dalam penelitian ini adalah metode penelitian tindakan kelas (PTK). Sampel yang digunakan dalam penelitian ini adalah mahasiswa pendidikan geografi yang mengikuti mata kuliah media pembelajaran geografi berbasis ICT. Pengumpulan data yang digunakan dalam penelitian ini berupa observasi, angket dan dokumentasi. Analisis data diperoleh dari hasil perolehan data observasi dan angket yang dianalisis dengan menggunakan analisis persentase. Setelah melaksanakan tindakan kelas yang dilaksanakan sebanyak 2 siklus yang masingmasing terdiri dari dua kali pertemuan, secara keseluruhan baik disiplin waktu dan disiplin perbuatan menunjukkan peningkatan 87,4\%. Persentase tersebut, lebih dari ketuntasan minimum ketercapaian. Dengan demikian, maka dapat disimpulkan bahwa upaya meningkatkan softskill disiplin mahasiswa pendidikan geografi melalui penggunaan Edomodo dengan metode blended learning telah tercapai dengan baik.
\end{abstract}

Kata Kunci : softskill disiplin, Edmodo, blended learning

\begin{abstract}
The purpose of this study was to determine the increase in the discipline of geography education students through the use of Edmodo with the blended learning method. The method used in this study is the classroom action research (CAR) method. The sample used in this study was geography education students who took ICT-based geography learning media subject. Data collection used in this study in the form of observation, questionnaires, and documentation. Data analysis was obtained from the results of observations and questionnaire data were analyzed using percentage analysis. Overall both time discipline and discipline of action showed an increase of $87.4 \%$. This percentage is more than the minimum achievement. Thus, it can be concluded that efforts to improve the discipline of geography education students through the use of Edmodo with the blended learning method have been well achieved.
\end{abstract}

Kata Kunci : softskills discipline, Edmodo, Blended Learning

\section{PENDAHULUAN}

Penggunaan teknologi internet dalam pembelajaran belakangan ini bukan lagi suatu hal yang baru dalam dunia pendidikan. Teknologi memiliki peran penting dalam dunia pendidikan baik admnistrasi maupun proses pembelajaran. Dalam proses pembelajaran, penggunaan teknologi menjadi sarana bagi pendidik dalam mentransformasikan pengetahuan dan mengembangkan potensi. Potensi menurut KBBI versi $\mathrm{V}$ merupakan kemampuan yang mempunyai kemungkinan untuk dikembangkan. Dalam hal ini adalah kemampuan mahasiswa yang merupakan objek dari civitas akademik yang memungkinkan dapat dikembangkan potensinya.

Universitas PGRI Palembang merupakan salah satu institusi pendidikan tinggi swasta di Sumatera Selatan memiliki tujuan yang salah satunya adalah menghasilkan lulusan yang berkompeten dan berdaya saing.
Agar tercapainya tujuan tersebut, dosen memiliki tugas dan tanggung jawab yang sangat penting tidak hanya mentransformasikan pengetahuan dan mengembangkan hardskill tetapi juga pentingnya mengembangkan softskill. Sebab mahasiswa merupakan individu dan juga calon lulusan yang harus dibekali sejumlah softskill agar mampu beradaptasi ketika berada dalam dunia kerja dan lingungannya. Elfindri (2011) mengungkapkan bahwa softskills dapat menentukan arah pemanfaatan hardskills. Jika seseorang memilikinya dengan baik, maka ilmu dan keterampilan yang dikuasainya dapat mendatangkan kesejahteraan dan kenyamanan bagi pemiliknya dan lingkungannya. Sebaliknya, jika seseorang tidak memiliki soft skills yang baik, maka hardskills dapat membahayakan diri sendiri dan orang lain. Sulianta (2018) menyatakan bahwa pada dasarnya, softskill adalah kombinasi antara 
keterampilan orang, keterampilan sosial, kemampuan berkomunikasi, karakter, sikap, atribut karier, kecerdasan social dan Emotional Intelligence Quotie nt (EQ) yang memungkinkan orang mengamati berbagai hal yang ada pada lingkungannya, memudahkannya dalam bekerja dengan orang lain dan berkinerja baik.

Namun kenyataan dilapangan, berdasarkan hasil evaluasi pembelajaran mata kuliah Media Pembelajaran Geografi Berbasis ICT selama semester ganjil dalam beberapa kali pertemuan di program studi Pendidikan Geografi Universitas PGRI Palembang menunjukkan bahwa mahasiswa kurang disiplin dalam mengikuti pembelajaran dikelas terutama dalam mengumpulkan tugas-tugas yang telah diberikan dan menyampaikan dengan beragam alasan, seperti kelupaan, kebanyakan tugas, ketinggalan padahal tidak setiap pertemuan diberikan tugas. Dalam proses penilaian pada mata kuliah ini, tidak hanya penilaian kognitif tetapi juga penilaian psikomotorik dan juga sikap mahasiswa selama perkuliahan. Meskipun begitu, peneliti menyadari bahwa dalam proses pembelajaran cenderung menekankan pada aspek kognitif dan psikomotorik. Sedangkan aspek sikap yang merupakan aspek penting dalam pengembangan softskill kurang menjadi dominan dalam proses pembelajaran. Temuan tersebut, selama perkuliahan kepada mahasiswa khususnya kedisiplinan menjadi penting bagi peneliti untuk meningkatkan softskill disiplin mahasiswa. Apalagi mahasiswa pendidikan geografi merupakan calon pendidik yang nantinya akan mengajar dan mendidik peserta didiknya maka, calon guru selain memiliki keterampilan/ hardskill pengajaran calon guru juga harus memiliki softskill terutama softskill disiplin.

Agar disiplin mahasiswa dapat ditingkatkan, maka diperlukan suatu strategi yang menunjang terlaksananya pembelajaran dengan baik. Berbagai strategi pembelajaran dapat diterapkan untuk melatih mahasiswa sehingga menjadi pribadi yang utuh dengan hardskills dan softskills yang balance (Delita, Elfayetti, dan Sidauruk, 2016). Mengingat penggunaan teknologi internet saat ini sudah banyak digunakan oleh mahasiswa baik untuk bersosial media maupun aktivitas lainnya, penggunaan teknologi internet dalam pembelajaran merupakan hal yang tepat untuk mendukung proses pembelajaran dan banyak digunakan untuk menunjang pembelajaran di kelas, salah satunya adalah Edmodo. Edmodo merupakan platform yang dikembangkan untuk memudahkan pendidik dan siswa dalam proses pembelajaran. Platform ini aman dan mudah untuk digunakan (user friendly), menggabungkan aspek pedagogik secara tradisional dan pedagogik abad ke-21 (Kayaizmir dalam Yuniarti \& Ifadah, 2018).

Edmodo dapat dimanfaatkan ke dalam pembelajaran, seperti penggunaan fitur quis untuk untuk mengukur kognitif mahasiswa menunjukkan bahwa kemampuan kognitif mahasiswa. Penelitian Murjainah (2016) menunjukkan bahwa dalam penggunaan fitur quis Edmodo mahasiswa dapat menggunakan fitur tersebut dengan sangat baik sedangkan rerata nilai hasil quis mahasiswa memperoleh nilai 70 dikelas V A, 80 dikelas V B dan 84 dikelas V C. Kemudian, Edmodo dapat juga diterapkan dengan metode blended learning. Blended learning merupakan pembelajaran yang menggabungkan pembelajaran konvensional dan online. Mahasiswa dapat menggunakan Edmodo tidak hanya di dalam kelas tetapi juga dapat digunakan diluar kelas dimana saja dan kapan saja untuk mengakses/ berbagi pengetahuan dalam grup kelas, mengerjakan tugas ataupun soal-soal quis. Penelitian Murjainah (2019) menunjukkan bahwa keterampilan mahasiswa dalam penggunaan Edmodo sudah cukup baik dalam menggunakan fitur-fitur Edmodo. Fitur-fitur tersebut diantaranya fitur group, assignment, quiz, progress.

Selain itu, adanya fitur lock pada Edmodo yang terdapat dalam fitur tugas sehingga diharapkan dapat meningkatkan softskill disiplin mahasiswa dalam pembelajaran. Fitur lock tersebut memungkinkan mahasiswa untuk disiplin terhadap pembelajaran. Selanjutnya, dalam penelitian lain mengenai penggunaan Edmodo dengan metode blended learning dapat meningkatkan softskill motivasi mahasiswa baik dalam pembelajaran maupun dalam menyelesaikan tugas-tugas yang ditunjukkan dengan peningkatan $85.4 \%$ dari $71.7 \%$ (Murjainah, Mujib, Aryaningrum, Arisman, dan Selegi, 2019). Sementara itu, Hamidah dan Palupi (2012) dalam penelitiannya mengenai 
peningkatan soft skills tanggung jawab dan disiplin terintegrasi melalui pembelajaran praktik patiseri menunjukkan bahwa melalui pembelajaran praktik, baik dalam kerja kelompok maupun individu mahasiswa telah mampu menunjukkan kinerja tanggung jawab, persiapan diri, persiapan kerja, proses produksi, penyajian, dan berkemas antara hampir selalu dan konsisten. Demikian halnya dengan kinerja disiplin telah memberi makna bagi penguasaan soft skills antara hampir selalu dan konsisten.

Dengan demikian, perlunya upaya meningkatkan softskill disiplin mahasiswa terutama displin mahasiswa dalam menyelesaikan tugas-tugas yang diberikan melalui penggunaan Edmodo dengan metode blended learning agar tercapainya kinerja akademik mahasiswa. Disiplin memainkan peran penting dalam kinerja akademik dengan menunjukkan bahwa disiplin diri berhubungan positif dengan prestasi akademik (Simba, Agak, \& Kabuka, 2016).

\section{Blended Learning}

Blended Learning berasal dari dua kata yaitu Blended dan Learning. Blended artinya campuran/ gabungan/kombinasi, sedangkan learning artinya belajar/pembelajaran. Jadi, Blended learning adalah pembelajaran campuran. Blended learning pada awalnya adalah aktivitas pembelajaran yang mengkombinasikan pertemuan tatap muka dengan pembelajaran elektronik seperti televisi, dan radio dalam pembelajaran perkembangan pembelajaran elektronik bergeser ke penggunaan jaringan, sehingga berkembang menjadi online learning (Smaldino, Lowther, dan Russel dalam Rahmi \& Azrul, 2019). Menurut Tucker (2012) blended learning merupakan satu kesatuan yang kohesif (berpadu /melekat), maksudnya adalah memadukan atau menggabungkan pembelajaran tradisional tatap muka dengan komponen online. Beberapa pengertian tersebut dapat disimpulkan bahwa blended learning adalah suatu proses pembelajaran yang memadukan pembelajaran trandisional tatap muka dengan online.

Menurut Tucker (2012) secara umum Blended Learning terdapat 6 model, yaitu:

a) Face-to-Face Driver : melibatkan siswa tidak hanya sekedar tatap muka di ruang kelas atau laboratorium, melainkan melibatkan siswa dalam kegiatan di luar kelas dengan mengintegrasikan teknologi web secara online;

b) Rotation: mengintegrasikan pembelajaran online sambil bertatap muka di dalam kelas dengan pengawasan pendidik ;

c) Flex: memanfaatkan media internet dalam penyampai pembelajaran kepada peserta. Dalam hal ini peserta dapat membentuk kelompok diskusi;

d) Online Lap : pembelajaran yang berlangsung di dalam ruang laboratorium komputer dengan semua materi pembelajaran di sediakan secara softcopy, di mana para peserta berinteraksi dengan pendidik secara online. Dalam hal ini guru dibantu oleh pengawas agar disiplin dalam belajar tetap terjaga;

e) Self Blend: dalam hal ini peserta mengikuti kursus online, hal ini sebagai pelengkap kelas tradisional yang dilakukan tidak mesti di dalam ruang kelas akan tetapi bisa di luar kelas ;

f) Online Driver : merupakan pembelajaran secara online, di mana dalam hal ini pendidik bisa meng-uplode materi pembelajaran di internet, sehingga peserta dapat mendownload/ mengunduhnya dari jarak jauh agar peserta bisa belajar mandiri di luar kelas dan dilanjutkan dengan tatap muka berdasarkan waktu yang telah disepakati

Langkah-langkah pembelajaran berbasis blended learning, diantaranya yaitu;

1) Kegiatan pembuka : dosen melakukan apersepsi dan menyampaikan tujuan perkuliahan

2) Kegiatan inti :

- Mahasiswa mengamati dan memperhatikan pengarahan/ penjelasan tutorial menggunakan edmodo yang disampaikan oleh dosen

- Mahasiswa menyimak materi perkuliahan yang disampaikan oleh dosen

- Dosen membagikan materi secara online dan mahasiswa mengunduh materi yang telah dibagikan

3) Kegiatan penutup

- Dosen dan mahasiswa menyimpulkan materi perkuliahan yang telah disampaikan oleh dosen 
- Dosen memberikan tugas secara online yang harus dikerjakan oleh mahasiswa secara mandiri di luar kelas

\section{Edmodo}

Edmodo adalah alat media pembelajaran elektronik sederhana yang digunakan untuk menyajikan isi pelajaran, biasanya semua sistem operasi smartphone ini menyediakan alat yang berguna bagi siswa dan guru untuk berinteraksi online di luar kelas dimana saja, kapan saja (Hourdequin dalam Hikmawan dan Sarino (2018). Sementara itu, Suriadhi (2014) mengungkapkan bahwa Edmodo merupakan platform media sosial yang sering digambarkan seperti facebook untuk sekolah dan dapat berfungsi lebih banyak lagi sesuai dengan kebutuhan guru dan siswa. Sejalan dengan Basori (2013) menyebutkan bahwa edmodo merupakan aplikasi yang menyerupai facebook tapi dengan nilai edukasi yang tinggi, sehingga menarik bagi guru dan siswa.

Bila Edmodo dibandingkan dengan media sosial Learning Manajemen System lainnya, menurut Priowirjanto dan Prapantja (2013) Edmodo memiliki beberapa kelebihan sebagai berikut:

(1) Mirip facebook, mudah digunakan,

(2) Closed group collaboration, hanya yang memiliki group code yang dapat mengikuti kelas,

(3) Free, diakses online, dan tersedia untuk perangkat smartphone, android dan iphone,

(4) Tidak memerlukan server di sekolah,

(5) Dapat diakses dimanapun dan kapanpun,

(6) Edmodo selalu di update oleh pengembang,

(7) Edmodo dapat diaplikasikan dalam satu kelas, satu sekolah, antar sekolah dalam satu kota atau kabupaten,

(8) Edmodo dapat digunakan bagi students, teacher dan parents,

(9) Edmodo digunakan untuk berkomunikasi dengan menggunakan model sosial media, learning material, dan evaluasi,

(10) Edmodo mendukung model team teaching, co-teacher, dan teacher,

(11) Terdapat notifikasi,

(12) Fitur badge dapat dimanfaatkan untuk meningkatkan motivasi siswa.

Sementara itu, Umaroh dalam Basori
(2013), mengungkapkan kelebihan dari edmodo adalah:

a) Membuat pembelajaran tidak bergantung pada waktu dan tempat.

b) Meringankan tugas guru untuk memberikan penilaian kepada siswa.

c) Memberikan kesempatan kepada orangtua/ wali siswa untuk memantau aktivitas belajar dan prestasi dari putra-putrinya.

d) Membuat kelas lebih dinamis karena memungkinkan interaksi guru dengan siswa maupun antara siswa dengan siswa dalam hal pelajaran atau tugas.

e) Memfasilitasi kerja kelompok yang multidisiplin.

f) Mendorong lingkungan virtual kolaboratif yang membantu pembelajaran berbasis proses.

Berdasarkan uraian tersebut, dapat disimpulkan bahwa Edmodo merupakan platform pembelajaran yang dapat digunakan untuk proses pembelajaran baik di dalam kelas maupun diluar kelas (pembelajaran virtual) dengan memasukkan materi, soal-soal sehingga pengguna dapat mempelajari materi pelajaran dan mengerjakan soal-soal. Artinya, Edmodo dapat dipadukan antara pembelajaran tradisional dan online. Dalam penelitian ini, peneliti menggunakan Edmodo untuk meningkatkan soft skill mahasiswa pendidikan Geografi.

\section{Softskill Disiplin}

LaFrance dalam Muhmin (2018) mengungkapkan soft skills didefinisikan sebagai "personal and interpersonal behaviour that develop and maximize human performance (e.g. confidence, flexibility, honesty, and integrity). Ini diartikan bahwa softskill merupakan perilaku personal dan interpersonal yang berkembang dan memaksimalkan kinerja, diantaranya percaya diri, fleksibel, kejujuran dan integritas.

Kemudian, menurut grugulis dalam Hamidah dan Palupi (2012) Softskills merupakan kompetensi yang bersifat nonteknis yang menunjuk pada karakteristik kepribadian. Hal tersebut tampak pada perilaku seseorang, baik saat berinteraksi dalam situasi sosial, kemampuan berbahasa, kebiasaan diri, ataupun sifat-sifat penting untuk mendukung perilaku optimis. Softskills sebagai kemampuan seseorang untuk memotivasi diri dan 
menggunakan inisiatifnya, mempunyai pemahaman tentang apa yang dibutuhkan untuk dilakukan dan dapat dilakukan dengan baik, berguna untuk mengatasi persoalan kecil yang muncul secara tiba-tiba dan terus dapat bertahan bila problem tersebut belum terselesaikan. Dengan demikian, softskill merupakan kompetensi non teknis merujuk pada perilaku personal dan interpersnonal seseorang yang berguna untuk mengatasi persoalan kecil yang muncul secara tiba-tiba dan dapat terus bertahan bila permasalahan belum terselesaikan.

Disiplin diri adalah penguasaan diri, pengekangan diri, keterandalan diri, dan kemandirian. Terdapat beberapa cara untuk menguatkan disiplin diri, diantaranya; putuskanlah bahwa kamu benar-benar ingin menjadi seseorang yang bersiplin diri; buatlah komitmen; pelajarilah aturan-aturan; bertanggungjawablah; latihlah; lakukanlah kegiatan-kegiatan yang meningkatkan disiplin dirimu; hapuskanlah kebiasaan-kebiasaan yang merugikan; dan mulailah kelompok pendukung disiplin diri (Hamidah dan Palupi, 2012).

Sementara itu, Semiawan, (2009) mendefinisikan bahwa disiplin secara luas dapat diartikan sebagai semacam pengaruh yang dirancang untuk membantu anak agar mampu menghadapi tuntutan dari lingkungan. Disiplin dikelompokkan sebagai disiplin pribadi, disiplin social, disiplin nasional, disiplin ilmu, disiplin tugas. Disiplin terdiri dari tiga aspek, yaitu sebagai berikut: (1) Sikap mental (mental attitude) yang merupakan sikap taat dan tertib sebagai hasil atau pengembangan dan latihan pengendalian pikiran dan pengendalian watak; (2) Pemahaman yang baik mengenai sistem aturan tingkah laku, pemahaman tersebut menumbuhkan atau kesadaran untuk memahami disiplin sebagai suatu aturan yang membimbing tingkah laku; (3) Sikap dan tingkah laku yang secara wajar menunjukkan kesungguhan hati untuk mentaati segala hal secara cermat (Bahri, 2008). Sementara itu, Moenir (2010) membagi disiplin menjadi dua, yaitu disiplin waktu dan disiplin perbuatan. Softskill disiplin yang dimaksudkan dalam penelitian ini adalah sikap kepatuhan dan penguasaan diri mahasiswa dalam berdisiplin terhadap tugas yang dilihat dari disiplin terhadap waktu dan disiplin dalam berprilaku. Softskill disiplin yang dimaksudkan dalam penelitian ini adalah sikap disiplin mahasiswa pendidikan geografi baik disiplin terhadap waktu dan disiplin perbuatan dalam menyelesaikan tugas melalui penggunaan Edmodo dengan metode blended learning.

Berdasarkan, uraina tersebut maka rumusan masalah dalam penelitian ini adalah bagaimanakan upaya meningkatkan softskill disiplin mahasiswa pendidikan geografi melalui penggunaan Edmodo dengan metode blended learning?. Adpun tujuan dalam penelitian ini adalah untuk mengetahui peningkatan disiplin mahasiswa pendidikan geografi melalui penggunaan Edmodo dengan metode blended learning.

\section{METODE}

Metode yang digunakan dalam penelitian ini adalah metode penelitian tindakan kelas (PTK). Menurut Arikunto, Suhardjono dan Supardi (2015) penelitian tindakan kelas adalah penelitian yang memaparkan terjadinya sebab-akibat dari perlakuan, sekaligus memaparkan apa saja yang terjadi ketika perlakuan diberikan dan memaparkan seluruh proses sejak awal pemberian perlakuan sampai dengan dampak dari perlakuan tersebut.

Langkah-langkah pelaksanaan tindakan
kelas penggunaan Edmodo untuk meningkatkan softskill disiplin mahasiswa peneliti mengadopsi Arikunto, Suhardjono dan Supardi (2017), antara lain siklus I terdiri dari 1) tahap perencanaan, terdiri dari kegiatan pelaksanaan yang dilakukan diantaranya menyusun Rencana Pembelajaran Semester (RPS) yang berisi tahapan pembelajaran dengan menggunakan edmodo dengan metode blended learning, menyiapkan lembar observer, menyiapkan catatan lapangan yang akan digunakan pada saat pelaksanaan pembelajaran, menyiapkan rancangan kelas edmodo, menyiapkan materi dan tugas-tugas yang diberikan kepada pembelajar; 2) tahap pelaksanaan terdiri dari melaksanakan tindakan kelas sesuai dengan perecanaan yang telah dibuat, memberikan pengarahan dan penjelasan penggunaan edmodo, menyampaikan perkuliahan secara blended learning dengan menggabungkan pertemuan tatap muka dan online, pembagian angket di akhir pertemuan, dan 3) tahap refleksi, terdiri dari refleksi dilakukan pada saat pertemuan yang dilakukan 
secara online dan tatap muka di kelas.

Berdasarkan hasil pengamatan dan catatan lapangan menjadi acuan dalam mengidentifikasi permasalahan yang muncul dalam penggunaan edmodo dengan metode blended learning selama kegiatan perkuliahan, merencanakan dan menyusun perbaikan tindakan berdasarkan identifikasi masalah yang ditemukan, kemudian penyusunan tindakan tersebut di implementasikan pada siklus berikutnya. Kemudian, kegiatan yang dilaksanakan pada siklus II, dimaksudkan digunakan dalam penelitian ini berupa observasi, angket dan dokumentasi. Observasi dilakukan bertujuan untuk mengamati perilaku mahasiswa selama proses pemberlajaran. Angket diberikan kepada mahasiswa setelah melaksanakan pembelajaran di kelas dan penggunaan Edmodo di luar kelas dalam mengerjakan tugas di Edmodo.

Analisis data diperoleh dari hasil perolehan data observasi dan angket yang dianalisis dengan menggunakan analisis persentase. Penggunaan Edmodo dengan metode blended learning dalam meningkatkan sotfskill disiplin mahasiswa bila telah mencapai $80 \%$ ketuntasan minimum. Untuk mengelompokkan perolehan data tersebut, menggunakan kelompok kategori seperti pada table 1 berikut.

Tabel 1. Interval Penilaian Persentase

\begin{tabular}{|c|c|}
\hline Persentase (\%) & Kategori \\
\hline $76-100$ & Baik \\
\hline $56-75$ & Cukup \\
\hline $40-55$ & Kurang baik \\
\hline $0-39$ & Tidak baik \\
\hline
\end{tabular}

Sumber : Arikunto, 2010

\section{HASIL DAN PEMBAHASAN}

Penelitian ini bertujuan untuk meningkatkan softskill disiplin mahasiswa pendidikan geografi melalui penggunaan Edmodo berbasis blended learning. Penelitian tindakan kelas ini dilaksanakan sebanyak dua siklus, masing-masing siklus terdiri dari dua kali pertemuan dan dua kali refleksi, yaitu refleksi saat siklus I dan refleksi siklus II.

Disiplin merupakan kepatuhan individu terhadap suatu aturan yang telah ditetapkan dan untuk perbaikan dari siklus I. Jika hasil data memenuhi target yang dicapai sesuai dengan indikator keberhasilan, maka proses kegiatan bisa dihentikan. Tetapi apabila belum memenuhi target pencapaian, maka penelitian tindakan dilanjutkan pada siklus III.

Sampel yang digunakan dalam penelitian ini adalah mahasiswa pendidikan geografi yang mengikuti mata kuliah media pembelajaran geografi berbasis ICT. Pengumpulan data yang

salah satu prilaku/ sikap yang dapat menuntun seseorang meraih keberhasilan. Disiplin adalah komponen penting dari perilaku manusia dan tanpanya organisasi tidak dapat berfungsi dengan baik menuju pencapaian tujuannya (Ouma, Simatwa, dan Serem, 2013).

Indikator disiplin yang menjadi menjadi perhatian peneliti selama proses penelitian. Indikator disiplin yang dimaksudkan dalam penelitian ini, disiplin waktu dan disiplin tindakan. Indikator ini menyelaraskan dengan penggunaan Edmodo dengan metode blended learning. Indikator disiplin diantaranya mahasiswa tepat waktu dalam mengerjakan tugas yang telah di-input-kan di Edmodo, mahasiswa tidak meninggalkan kelas selama berlangsungnya pembelajaran di kelas. Sedangakan disiplin perbuatan, diantaranya kepatuhan mahasiswa / tidak menentang tugas yang diberikan, tidak malas mengerjakan tugas yang diberikan, dan tidak menugaskan orang lain untuk mengerjakan tugas yang diberikan.

Untuk mengetahui perilaku disiplin mahasiswa selama pembelajaran berlangsung dilakukan pengamatan/ observasi sedangkan untuk mengetahui softskill disiplin mahasiswa dilakukan pengambilan angket kepada mahasiswa setelah dilaksanakan pembelajaran di setiap akhir pertemuan agar dapat diketahui sejauh mana peningkatan softskill mahasiswa dalam menggunakan Edmodo baik di kelas maupun diluar kelas selain diperoleh dari proses pengamatan selama pembelajaran di kelas. Hasil analisis mengenai softskill disiplin melalui penggunaan Edmodo dengan metode blended learning dapat dilihat pada gambar 2 berikut. 


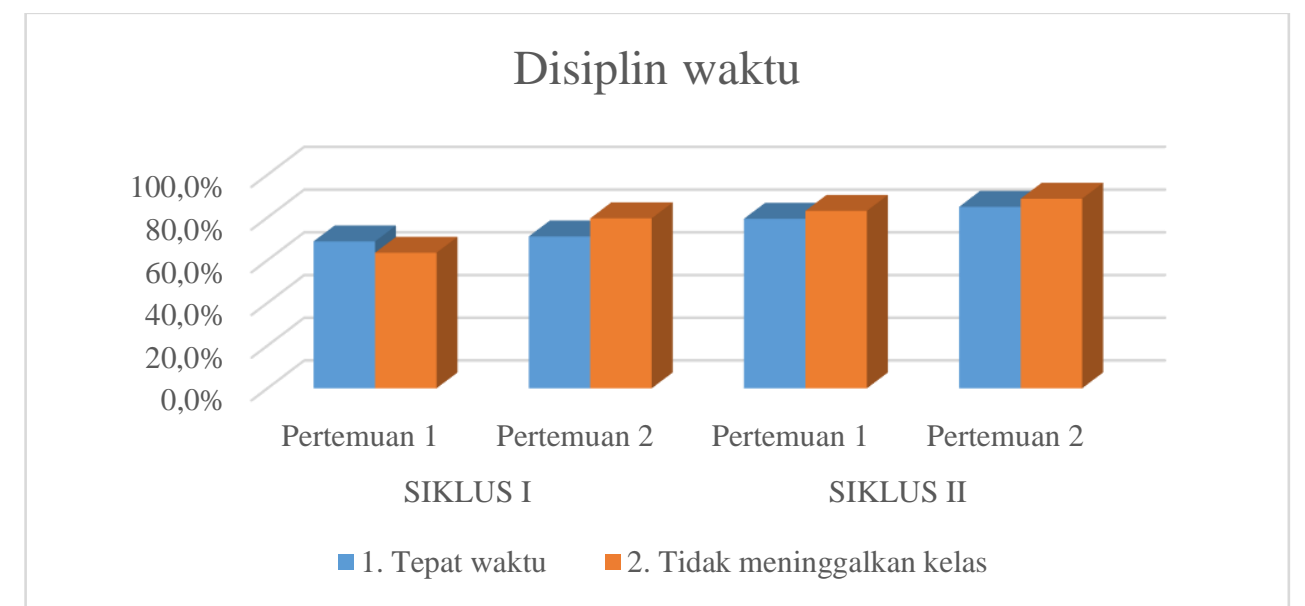

Gambar 1. Disiplin Waktu Mahasiswa Melalui Penggunaan Edmodo dengan metode Blended Learning ( Sumber : Hasil Pengolahan Data, 2019).

Bila diperhatikan pada gambar 2 sikap disiplin terhadap waktu mahasiswa melalui penggunaan Edmodo dengan metode blended learning mengalami peningkatan hingga pertemuan 2 siklus II. Dari hasil analisis tersebut menunjukkan bahwa sikap disiplin untuk tepat waktu mahasiswa dalam mengumpulkan tugas dari $68,8 \%$ di pertemuan 1 pada siklus I meningkat menjadi $85 \%$ di pertemuan 2 pada siklus II. Kemudian, mahasiswa tidak meninggalkan kelas selama pembelajaran berlangsung sebesar $88,8 \%$ dari pertemuan sebelumnya di pertemuan 1 siklus I sebesar $63,5 \%$. Selanjutnya, dilihat dari tugas mahasiswa di Edmodo, terdapat beberapa mahasiswa yang tidak disiplin waktu dalam mengerjakan tugas mereka di Edmodo ini nampak pada tugas mereka di Edmodo.

Jadi, bila dilihat secara keseluruhan menunjukkan bahwa penggunaan Edmodo dengan metode blended learning meningkatkan softskill mahasiswa pendidikan geografi yang terlihat pada grafik terdapat peningkatan di akhir pertemuan 2 pada siklus II, yaitu lebih dari $80 \%$ ketuntasan minimum ketercapaian pembelajaran. Maka, dalam penggunaan Edmodo dengan metode blended learning termasuk dalam kategori baik untuk meningkatkan softskill disiplin mahasiswa. Penggunaan waktu yang efisien secara langsung berhubungan dengan peningkatan kinerja akademik (Kelly, 2004). Tampilan dari fitur tugas Edmodo pada gambar 3 berikut.

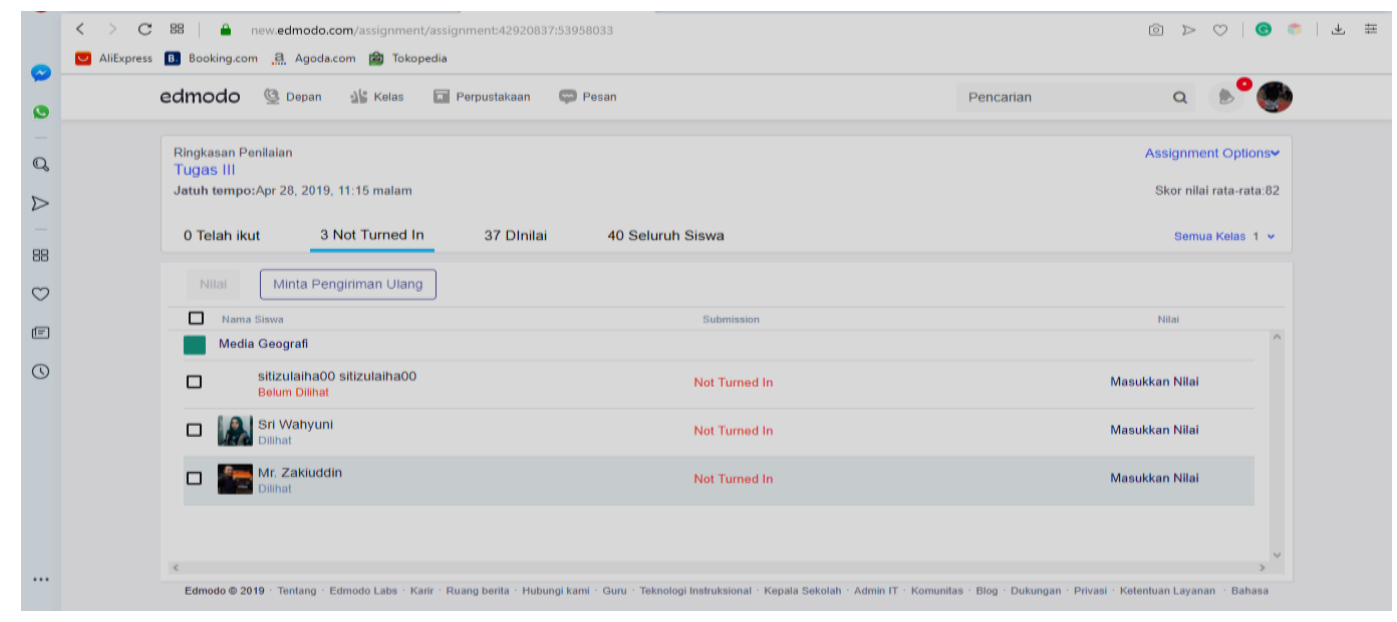

Gambar 2. Disiplin Waktu Penggunaan Edmodo dengan metode blended learning dilihat dari Fitur Tugas mengumpulkan tugas (Sumber : Dokumentasi Penulis) 


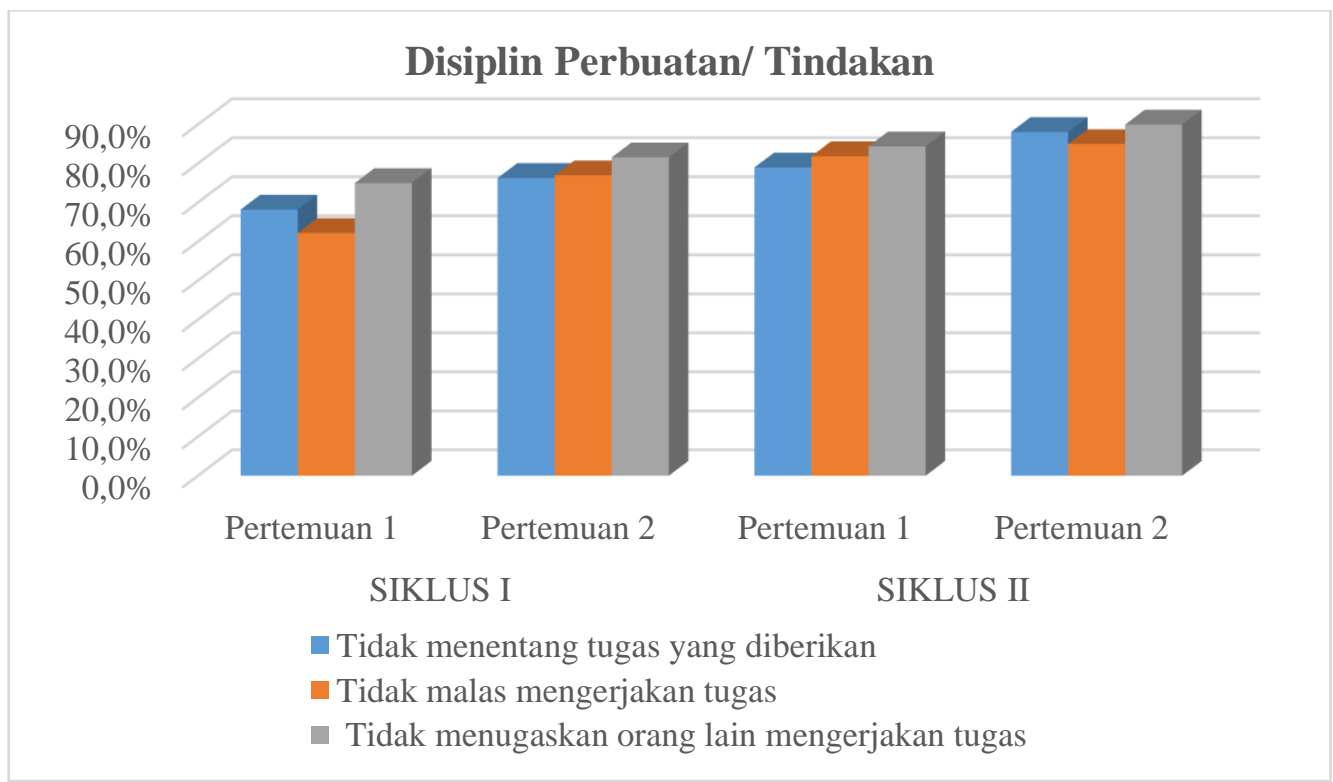

Gambar 3. Softskill Disiplin Perbuatan/ Tindakan Mahasiswa Melalui Penggunaan Edmodo dengan metode Blended Learning ( Sumber : Hasil Pengolahan Data, 2019).

\begin{abstract}
Berdasarkan gambar 3, disiplin perbuatan/ tindakan mahasiswa melalui penggunaan Edmodo dengan metode blended learning juga mengalami peningkatan di pertemuan ke-2 siklus II, diantaranya mahasiswa tidak menentang tugas yang diberikan mengalami peningkatan sebesar $88,1 \%$ dari $68,2 \%$, tidak malas mengerjakan tugas meningkat $85 \%$ dari $62,2 \%$ dan tidak meminta orang lain untuk mengerjakan tugas meningkat $90 \%$ dari $75 \%$. Bila disiplin perbuatan ini direratakan maka penggunaan Edmodo telah meningkatkan soft skill disiplin sebesar $87,4 \%$.
\end{abstract}

Jadi, penggunaan Edmodo dengan metode blended learning termasuk dalam kategori baik dalam meningkatkan softskill disiplin. Ini terlihat pula pada aktivitas mahasiswa selama proses pembelajaran berlangsung pada pertemuan pertama beberapa mahasiswa tidak hadir dalam proses pembelajaran, datang terlambat, ijin keluar kelas, dan kurang memperhatikan penjelasan/ pengarahan. Namun, pada pertemuan berikutnya mahasiswa yang datang terlambat, ijin keluar kelas, dan kurang memperhatikan penjelasan/ pengarahan berkurang. Ini menunjukkan bahwa peningkatan disiplin mahasiswa baik disiplin waktu maupun disiplin tindakan menimbulkan kepatuhan bagi mahasiswa dengan tidak menyerahkan tugas pada orang lain, tidak menentang tugas yang diberikan, serta tidak malas mengerjakan tugas yang diberikan. Mahasiswa yang disiplin adalah mahasiswa yang perilaku dan tindakantindakannya sesuai dengan peraturan yang telah ditentukan sebelumnya (Ali, Dada, Isiaka, \& Salmon, 2014).

\section{SIMPULAN}

Setelah melaksanakan tindakan kelas yang dilaksanakan sebanyak 2 siklus yang masing-masing terdiri dari dua kali pertemuan, secara keseluruhan baik disiplin waktu dan disiplin perbuatan menunjukkan peningkatan $87,4 \%$. Persentase tersebut, lebih dari ketuntasan minimum ketercapaian. Dengan demikian, maka dapat disimpulkan bahwa upaya meningkatkan softskill disiplin mahasiswa pendidikan geografi melalui penggunaan Edomodo dengan metode blended learning telah tercapai dengan baik.

\section{Saran}

Bagi penliti lain, perlunya mengkaji lebih lanjut potensi-potensi softskill yang lain dalam penggunaan Edmodo dengan strategi pembelajaran yang berbeda.

\section{Ucapan Terimakasih}

Terimakasih kepada Kemenristekdikti yang telah memberikan kesempatan meneliti 
melalui Dana Hibah Penelitia Dosen Pemula (PDP) Pendanaan Tahun 2019.

\section{DAFTAR PUSTAKA}

Ali, A., Dada, I., Isiaka, G., \& Salmon, S. (2014). Types, Causes and Management of Indicipline Acts Among Secondary School Students in Shomolu Local Government Area of Lagos State. Journal of Studies in Social Sciences, 154-287.

Bahri, S. (2008). Tanggung Jawab, Disiplin, Jujur itu Keren. Jakarta: KPK Direktorat Pendidikan dan Pelayanan Masyarakat.

Basori. (2013). Pemanfaatan Social Learning Network "Edmodo" dalam Membantu Perkuliahan Teori Bodi Otomotif di Prodi PTM JPTK FKIP UNS. JIPTEK, 99-105.

Delita, F., Elfayetti, \& Sidauruk, T. (2016). Peningkatan Softskills dan Hardskills Mahasiswa Melalui Project-Based Learning Pada Mata Kuliah Perencanaan Pembelajaran Geografi. Jurnal Geografi ISSN 2085 - 8167, 124-135.

Elfindri, d. (2011). Softskill Untuk Pendidik. Bandung: Praninta Offset.

Hamidah, S., \& Palupi, S. (2012). Peningkatan Softskill Tanggungjawab dan Disiplin Terintegrasi Melalui Pembelajaran Praktik Patiseri. Jurnal Pendidikan Karakter Tahun II, Nomor 2., 143-152.

Hikmawan, T., \& Sarino, A. (2018). Pemanfaatan media pembelajaran berbasis edmodo terhadap. Jurnal Pendidikan Manajemen Perkantoran, 226-233.

Kelly, W. (2004). As Achievement Sails the River of Time: The Role of Time Use Efficiency in Grade-Point-Average. Educational Research Quarterly Vol. 27 No.4, 3-8.

Moenir. (2010). Masalah-Masalah dalam Belajar. Yogyakarta: Pustaka Pelajar.

Muhmin, A. H. (2018). Pentingnya Pengembangan Softskill Mahasiswa di Perguruan Tinggi. Forum Ilmiah Volume 15 Nomor 2 , 330-338.

Murjainah. (2016). Penggunaan Fitur Quis Edmodo Untuk Mengukur Kemampuan Kognitif Mahasiswa Pendidikan Geografi pada Mata Kuliah Geografi Hewan dan Tumbuhan. Seminar Nasional Pendidikan Serentak Se Indonesia (pp. 690-697).
Semarang: Universitas Negeri Semarang. Murjainah. (2019). Keterampilan Mahasiswa Pendidikan Geografi dalam Menggunakan Edmodo Berbasis Blended Learning. Prosiding Seminar Nasional Pendidikan FKIP (pp. 389-401). Serang: Universitas Sultan Ageng Tirtayasa.

Murjainah, Mujib, M. A., Aryaningrum, K., Arisman, \& Selegi, S. F. (2019). Improvement Of Students' Soft Skills (Honesty And Motivation) Using Edmodo By Blended Learning Method. International Conference on Environmental Geography and Geography Education. Jember: Universitas Jember.

Ouma, M., Simatwa, E., \& Serem, T. (2013). Management of Pupil Dicipline in Kenya: A Case Study of Kisumu Municipality. Educational Research, 374-386.

Priowirjanto, G., \& Prapantja, Y. (2013). Materi Simulasi Digital: Where Learning Happens. Southeast Asian Ministers of Education Organization.

Rahmi, U., \& Azrul. (2019). Transformasi Pembelajaran untuk Menciptakan Pengalaman Penggunaan TIK melalui Blended Learning. Edutech, 246-262.

Semiawan, C. (2009). Penerapan Pembelajaran Pada Anak. Jakarta: Penerbit Ideks.

Simba, N. O., Agak, J. O., \& Kabuka, E. K. (2016). Impact of Discipline on Academic Performance of Pupils in Public. Journal of Education and Practice, 164-173.

Sulianta, F. (2018). Panduan Lengkap Pengembangan Softskill Interpersonal dan Interpersonal Skill. Yogyakarta: Andi Offset.

Suriadhi, G. (2014). Pengembangan ELearning Berbasis Edmodo Pada Mata Pelajaran IPA Kelas VIII di SMPN 2 Singaraja. journal Edutech.

Tucker, C. (2012). Blended Learning in Grades 4-12. London: Corwin Press.

Yuniarti, N. E., \& Ifadah, M. (2018). Keefektifan Penggunaan Aplikasi Edmodo dalam Pembelajaran Bahasa. Prosiding Seminar Nasional Mahasiswa Unimus (Vol. 1, 2018) (pp. 460-464). Semarang: Universitas Muhamadiyah Semarang. 